\title{
INFLUENCE OF SECTION LENGTHS ON VOLUME DETERMINATION IN EUCALYPTUS TREES
}

\author{
Carlos Pedro Boechat Soares ${ }^{1}$, Gilson Fernandes da Silva² ${ }^{2}$ Fabrina Bolzan Martins ${ }^{3}$
}

(received: July 20, 2009; accepted: February 26, 2010)

\begin{abstract}
The aim of this work was to assess the influence of different section lengths on the determination of eucalyptus tree stem (with bark) volumes and its implications in forest inventory procedures. The 40 Eucalyptus grandis trees used, all from the municipality of Viçosa, Minas Gerais state, were 77 months old. The volume of the stems (with bark), whose maximum diameter was $3,0 \mathrm{~cm}$, was obtained through the Smalian formula, with sections 1.0, 2.0 and $3.0 \mathrm{~m}$ long. Longer sections lead to overestimations of the volume of the trees' basal part and, consequently, of their total volume. Different statistical tests led to different conclusions regarding the similar volume estimates resulting from experiments using different section lengths ${ }^{4}$. Volumetric equations adjusted with longer sections may introduce bias errors in forest inventory procedures.
\end{abstract}

Key words: Volumetric equations, Smalian formula, Eucalyptus grandis.

\section{INFLUÊNCIA DO COMPRIMENTO DAS SEÇÕES NA DETERMINAÇÃO DE VOLUMES DE ÁRVORES DE EUCALIPTO}

\begin{abstract}
RESUMO: Objetivou-se, neste trabalho, verificar a influência do comprimento das seções na determinação do volume dos fustes com casca de árvores de eucalipto e suas implicações nos procedimentos de inventário florestal. Para isso, foram utilizados dados de 40 árvores de Eucalyptus grandis, com 77 meses de idade, obtidos no município de Viçosa, Minas Gerais. Os volumes dos fustes com casca até um diâmetro limite igual a 3,0 cm foram obtidos utilizando-se a fórmula de Smalian, considerando seções de 1, 2 e 3 metros de comprimento. O aumento do comprimento das seções causa superestimativas dos volumes na parte basal das árvores e, consequentemente, dos volumes totais das árvores. Testes estatísticos distintos resultaram em conclusões diferentes quanto à igualdade das estimativas dos volumes obtidos com diferentes comprimentos de seções. Equações volumétricas ajustadas com seções de comprimentos maiores podem introduzir erros de tendência nos procedimentos de inventário florestal.
\end{abstract}

Palavras - chave: Equações volumétricas, fórmula de Smalian, Eucalyptus grandis.

\section{INTRODUCTION}

The main objective of forest surveys is to quantify volumetric stock. In order to do this, sample-based inventory procedures are used, in which tree volume is determined through volumetric equations and other procedures, such as volume ratio or taper models (CAMPOS \& LEITE, 2006).

The most widely used procedure is that of volumetric equations, usually adjusted by using data from scaling of the sample trees (SOARES et al., 2006). In scaling, stem volume may be obtained through water displacement (xylometer), which considered the real volume, or through mathematical equations such as Huber's, Newton's, Smalian's, Hohenald's, Pressler's, the centroid method and Hossfeld's equation, among others, all of which are estimatives of the real volume (LOETSCH et al., 1973; MACHADO \& FIGUEIREDO FILHO, 2003).

Opinions regarding the most precise formulas for carrying out the scaling differ among authors. The most widely used are Newton's, Huber's and Smalian's formulas (FINGER, 1992). Goulding (1979) and Husch et al. (1982) affirm that Newton's is the most precise formula, as it takes into account the different forms the tree stem can assume: cone, paraboloid, neiloid and cylinder. Finger (1992) highlights that the Huber and Smalian formulas are precise only when the stem resembles a paraboloid.

Huber's formula is more used in Europe due to its accuracy, while the Smalian is prefered in the USA due to its practicality, especially if the aim is also to quantify the logs piled together (LOETSCH et al., 1973). In Brazil, the Smalian formula is widely used to determine tree volume

\footnotetext{
${ }^{1}$ Forest Engineer, Professor, PhD in Forest Science - Departamento de Engenharia Florestal - Universidade Federal de Viçosa Viçosa, MG - 36571-000 - csoares@ufv.br

${ }^{2}$ Forest Engineer, Professor, PhD in Forest Science - Centro de Ciências Agrárias - Universidade Federal do Espírito Santo - Cx. P. 16 29500-000 - Alegre, ES - gfsilva2000@yahoo.com

${ }^{3}$ Forest Engineer, Assistant Professor - Universidade Federal de Itajubá, Doctoral student at the Programa de Pós-graduação em Ciência Florestal of Universidade Federal de Viçosa - Viçosa, MG - 36571-000 - fabrinabm@gmail.com
} 
and to adjust volumetric equations, in different native and exotic species (MACHADO et al., 2000, 2002, 2006; RIBEIRO et al., 2001; SCHNEIDER \& TONINI, 2003; SILVA et al., 1978; SOARES \& PAULA NETO, 1997; TONINI et al., 2005). According to Machado \& Figueiredo Filho (2003), this is due more to practicality than to accuracy.

As mentioned above, there are many different formulas for determining the volume of tree stems and also different results deriving from their use. However, little attention has been given to the influence of section length on volume.

The aim of this work was to assess the influence of section length in determining the volume of individual eucalyptus trees and its implications on forest inventory procedures, and also to assess the sensitivity of different statistical tests to the similar volume results obtained in experiments with different section lengths.

\section{MATERIAL AND METHODS}

\subsection{Description of the study area and the data}

This study was done using data from a 77 month-old Eucalyptus grandis plantation, in the municipality of Viçosa, Minas Gerais state. According to the Köppen classification, the climate in Viçosa belongs to type Cwa, subtropical. The mean temperature of the hottest month is above $22^{\circ} \mathrm{C}$, and the highest and lowest temperature means are $26.1^{\circ} \mathrm{C}$ and $14.0^{\circ} \mathrm{C}$, respectively. The summers are rainy and the winters dry, with an annual precipitation of 1.341.2 mm (VIANELLO \& ALVES, 1991).
To assess the behavior of the equations adjusted with different section lengths on volume determination, data from 38 permanent plots of a eucalyptus population encompassing an area of $630 \mathrm{~m}^{2}$ were used.

With the population's diametric distribution data, 40 sample trees were selected. The diameter of the eucalyptus stem with bark was measured at $1.30 \mathrm{~m}(\mathrm{DBH})$, and total tree height (HT) was determined. The same number of trees were sampled in all the diametric classes, as shown in Table 1.

To determine the volumes of the stems (with bark), scaling was done by successive application of the Smalian formula (HUSCH et al., 1993) on sections 1.0; 2.0 and $3.0 \mathrm{~m}$ long with a diameter limit of, approximately, $3 \mathrm{~cm}$.

\subsection{Analysis of the data}

To asses the influence of the section lengths on stem (with bark) volume estimatives, variation analysis (ANOVA), Tukey and "t" statistical tests were applied to pared data, and the identity of nonlinear models was tested.

To prove that the length of the sections and the diametric classes are important in estimating volume with bark, variation analysis (ANOVA) was done in a random block design in which the treatments were the section lengths $(1,0 ; 2,0$ and 3,0 meters) and the blocks were the diametric classes $(6.25 ; 8.75 ; 11.25 ; 13.75 ; 16.25 ; 18.75 ; 21.25$ and 23.75). To check if the volume results obtained with different section lengths varied significantly, the Tukey test was applied to compare the means. In both cases (ANOVA and Tukey test) the significance level was 5\%.

Table 1 - Number of trees per diameter and height class.

Tabela 1 - Número de árvores por classe de diâmetro e de altura.

\begin{tabular}{|c|c|c|c|c|c|c|c|c|c|c|c|c|}
\hline \multirow{2}{*}{ DBH class center $(\mathrm{cm})$} & \multicolumn{11}{|c|}{ Height class center (m) } & \multirow{2}{*}{ Overall total } \\
\hline & 11 & 13 & 15 & 17 & 19 & 21 & 23 & 25 & 27 & 29 & 31 & \\
\hline 6.25 & 1 & 4 & & & & & & & & & & 5 \\
\hline 8.75 & & & 2 & 2 & 1 & & & & & & & 5 \\
\hline 11.25 & & & & & & 3 & 2 & & & & & 5 \\
\hline 13.75 & & & & & & 3 & 2 & & & & & 5 \\
\hline 16.25 & & & & & & & & 3 & 2 & & & 5 \\
\hline 18.75 & & & & & & & & & 4 & 1 & & 5 \\
\hline 21.25 & & & & & & & & & 2 & 2 & 1 & 5 \\
\hline 23.75 & & & & & & & & & 1 & 3 & 1 & 5 \\
\hline Overall total & 1 & 4 & 2 & 2 & 1 & 6 & 4 & 3 & 9 & 6 & 2 & 40 \\
\hline
\end{tabular}

Cerne, Lavras, v. 16, n. 2, p. 155-162, abr./jun. 2010 
The $t$ test was applied to paired data, to compare if the differences between the volumes with bark, obtained using different section lengths, are statistically different (MAGALHÃES \& LIMA, 2004). The null hypothesis tested was that the means of the differences between the volume results is, statistically, zero. The " $\mathrm{t}$ " test significance level was $5 \%$.

The nonlinear model identity test was done later, where the Schumacher \& Hall (1933) volumetric equation was adjusted to the three section lengths, in their non-linear form. The Gauss-Newton method was used to adjust the Schumacher \& Hall equation:

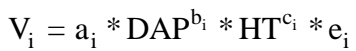

Where: $V_{i}=$ volume with bark, with sections 1.0; 2.0 and 3,0 meters long; $D B H=$ diameter with bark measured at 1,30 meters from the ground, in centimeters; $H T=$ total height of the trees, in meters; $a_{i}, b_{i} e c_{i}=$ model parameters for each section length; $\varepsilon_{\mathrm{i}}=$ random error.

The accuracy of the volume equations adjusted to each section length were verified, respectively, through the accuracy measurements: adjusted coefficient of determination $\left(\mathrm{R}_{\text {adj }}^{2}\right)$, standard estimative error, in percentage $\left(\mathrm{S}_{\mathrm{yx} \%}\right)$ and graphic analysis of the residues (CAMPOS \& LEITE, 2006; DRAPER \& SMITH, 1981).

The adjusted coefficient of determination $\left(\mathrm{R}^{2}{ }_{\text {adj }}\right)$ was determined through the following expression (KVALSETH, 1985):

$$
\begin{aligned}
& R^{2}=1-\frac{\left(\sum_{i=1}^{n}\left(Y_{i}-\hat{Y}\right)^{2}\right)}{\sum_{i=1}^{n}\left(Y_{i}-\bar{Y}\right)^{2}} \\
& \mathrm{R}_{\text {adj }}^{2}=1-\mathrm{a}\left(1-\mathrm{R}^{2}\right) \\
& \mathrm{a}=\frac{\mathrm{n}-1}{\mathrm{n}-\mathrm{p}-1}
\end{aligned}
$$

Where: $Y_{i}=i$-esimal value found for the dependant variable $\mathrm{Y}$, in this case the volume of the stem (with bark); $\hat{Y}_{i}=\mathrm{i}$ esimal value estimated for the dependant variable $\mathrm{Y} ; \bar{Y}=$ mean of the values found for the dependant variable $\mathrm{Y} ; \mathrm{n}-1=$ total degrees of freedom in the regression variation analysis; $\mathrm{n}-\mathrm{p}-1=$ degrees of freedom of the residue obtained from regression variation analysis.
The estimative standard error value, in percentage, was determined through the formula (BRUCE \& SCHUMACHER, 1950; SCHNEIDER, 1998):

$$
S_{y x}= \pm \frac{\sqrt{\frac{\sum_{i=1}^{n}\left(Y_{i}-\hat{Y}\right)^{2}}{n-p-1}}}{\bar{Y}} \times 100
$$

Where: $Y_{i}=i$-esimal value found for the dependant variable Y; $\hat{Y}_{i}=$ i-esimal value estimated for the dependant variable $\mathrm{Y} ; \bar{Y}=$ mean of the dependant variable $\mathrm{Y}$ values; $\mathrm{n}-\mathrm{p}-1=$ degrees of freedom of the residue obtained in the regression variation analysis.

To carry out the identity test, Regazzi's (2003) methodology for nonlinear models was used. In this methodology, the similarity of the equation coefficients can be tested by the Chi-square statistic, as follows:

$$
\chi_{\text {calculado }}^{2}=-\mathrm{n} * \ln \left(\frac{\mathrm{SQR}_{\mathrm{O}}}{\mathrm{SQR}_{\mathrm{w}}}\right)
$$

Where: $\chi_{\text {calculado }}^{2}=$ calculated ; $S Q R_{\Omega}=$ sum of the Chisquare complete model's residue squares; $S Q R_{w}=$ sum of the reduced model's residue squares; $\mathrm{n}=$ total amount of data.

The hypotheses tested in this work through the Chi-square statistic, were:

H0: $\mathrm{a} 1=\mathrm{a} 2=\mathrm{a} 3(=\mathrm{a}) ; \mathrm{b} 1=\mathrm{b} 2=\mathrm{b} 3(=\mathrm{b}) ; \mathrm{c} 1=\mathrm{c} 2=\mathrm{c} 3(=\mathrm{c})$ versus

Ha: there is at least one variation between the coefficients. Where: ai, bi e ci correspond to the Schumacher \& Hall (1933) model's parameters, for the three different section lengths.

Dispersion graphs were generated to assess the behavior of the volume estimates along the stem and between the different section lengths. The volumetric equations adjusted with different section lengths were applied to the inventory plot data to assess the influence on the volume estimates of the eucalyptus population.

\section{RESULTS AND DISCUSSION}

Scaled trees are usually used in profile studies or to develop volume or taper equations (CAMPOS \& LEITE, 2006; MACHADO \& FIGUEIREDO FILHO, 2003). Therefore, a small difference in section length can modify and compromise the results of a whole study that began with scaling.

Cerne, Lavras, v. 16, n. 2, p. 155-162, abr./jun. 2010 
In this wotk, there was a significant difference between the section lengths (effect of the treatment) and diametric classes (effect of the block), as $\mathrm{F}_{\text {cal }}>\mathrm{F}_{\mathrm{tab}}$. Therefore, there is at least one contrast between the treatment means that are statistically different from zero $(\mathrm{P}<0.05)$. (Table 2).

In the Tukey test (Table 3), the volume means found with sections 1.0 and $2.0 \mathrm{~m}$ long $\left(\mathrm{V}_{1 \mathrm{cc}} \mathrm{e}_{2 \mathrm{cc}}\right)$ are statistically the same, and are different from the volume mean found with $3.0 \mathrm{~m}$ long sections $\left(\mathrm{V}_{3 \mathrm{cc}}\right)$.

Analyzing Table 4, the volumes obtained using different section lengths varied statistically $(\mathrm{P}<0.05)$ in the t test.

The mean of the differences between the volume results using sections 1.0 and $2.0 \mathrm{~m}$ long $\left(\mathrm{V}_{1 \mathrm{cc}}-\mathrm{V}_{2 \mathrm{cc}}\right)$ was lower than the differences between sections $2.0-3.0 \mathrm{~m}$ long $\left(\mathrm{V}_{2 \mathrm{cc}}-\mathrm{V}_{3 \mathrm{cc}}\right)$. The greatest difference between the volume results was found with sections between $1-3 \mathrm{~m}$ long. Laar \& Akça (2007) highlight that the difference between the section lengths is due to the shape of the trees, which are predominantly neiloid at the base and paraboloid at the top.

The volume equations adjusted well to the data, in view of the estimates of the adjusted coefficients of determination and the standard estimate error, in percentage (Table 5). However, there was a small loss in the equation adjustments with the longer sections.

According to the results in Table 6, the null hypothesis of similar parameters in the Schumacher \& Hall model for the three section lengths should not be rejected. In other words, one single volume equation can be used for the three sections. The differences between the section lengths observed in the Tukey and $t$ tests were not observed in the application of the test, used to test Chi-square the identity of nonlinear models.

Table 2 - Variation analysis of the section lengths and diametric classes.

Tabela 2 - Análise de variância para comprimento de seções e classes diamétricas.

\begin{tabular}{lccccc}
\hline F.V. & GL & SQ & QM & $F_{\text {cal }}$ & $F_{\text {tab }}$ \\
\hline Treatment & 2 & 0.0001445 & $7.226 \mathrm{E}-05$ & 16.281175 & 3.7389 \\
Block & 7 & 0.6920435 & 0.09886336 & 22275.165 & 2.7642 \\
Residue & 14 & $6.214 \mathrm{E}-05$ & $4.4383 \mathrm{E}-06$ & & \\
\hline Total & 23 & 0.6922502 & & \\
\hline F.V. = variation source; GL = degrees of freedom; $\mathrm{SQ}=$ sum of the squares; $\mathrm{QM}=$ mean square; $\mathrm{F}_{\text {cal }}=$ calculated $\mathrm{F}$ values and \\
$\mathrm{F}_{\text {tab }}=$ F table value.
\end{tabular}

Table 3 - Tukey test applied to compare the volume with bark means obtained with sections 1,0;2,0 and 3,0 m long $\left(\mathrm{V}_{1 \mathrm{cc}}, \mathrm{V}_{2 \mathrm{cc}}\right.$ and $\left.\mathrm{V}_{3 \mathrm{cc}}\right)$.

Tabela 3 - Teste Tukey para comparação das médias dos volumes com casca obtidos com seções de comprimento iguais a 1,0m, 2,0 e 3,0 metros $\left(V_{I c c}, V_{2 c c}\right.$ e $\left.V_{3 c c}\right)$.

\begin{tabular}{cl}
\hline Volumes (treatments) & Means \\
\hline $\mathrm{V}_{3 c \mathrm{cc}}$ & $0.2252 \mathrm{a}$ \\
$\mathrm{V}_{2 c c}$ & $0.2216 \mathrm{~b}$ \\
$\mathrm{~V}_{1 \mathrm{cc}}$ & $0.2193 \mathrm{~b}$ \\
\hline
\end{tabular}

* means followed by the same letter do not differ statistically in the Tukey test, at a $95 \%$ probability level.

Table 4 - $\mathrm{t}$ test to compare the volumes with bark obtained with sections 1,0; 2,0 and 3,0 m long $\left(\mathrm{V}_{1 \mathrm{cc}}, \mathrm{V}_{2 \mathrm{cc}} \mathrm{e} \mathrm{V}_{3 \mathrm{cc}}\right)$.

Tabela 4 - Teste t para comparação entre os volumes com casca, obtidos com seções de 1,0, 2,0 e 3,0 metros $\left(V_{l c c}, V_{2 c c}\right.$ e $\left.V_{3 c c}\right)$.

\begin{tabular}{cccc}
\hline & \multicolumn{3}{c}{ Mean of the differences between the volumes } \\
\cline { 2 - 4 } & $\mathrm{V}_{1 \mathrm{cc}}-\mathrm{V}_{2 \mathrm{cc}}$ & $\mathrm{V}_{1 \mathrm{cc}}-\mathrm{V}_{3 \mathrm{cc}}$ & $\mathrm{V}_{2 \mathrm{cc}}-\mathrm{V}_{3 \mathrm{cc}}$ \\
\hline $4.30^{*}$ & $5.70^{*}$ & $4.53^{*}$ \\
\hline
\end{tabular}

* significant, at a $95 \%$ probability level.

Cerne, Lavras, v. 16, n. 2, p. 155-162, abr./jun. 2010 
Table 5 - Estimates of the adjusted equation parameters, adjusted coefficient of determination $\left(\mathrm{R}^{2}{ }_{\text {adj }}\right)$ and estimate standard error $\left(\mathrm{S}_{\mathrm{yx} \%}\right)$, according to the different section lengths.

Tabela 5 - Estimativas dos parâmetros das equações ajustadas, coeficiente de determinação ajustado ( $R_{\text {adj }}^{2}$ ) e erro padrão da estimativa $\left(S_{y x \%}\right)$ considerando-se diferentes comprimentos de seções.

\begin{tabular}{|c|c|c|c|}
\hline Parameters & Parameter estimates & $R_{\text {adj }}^{2}$ & $\mathrm{~S}_{\mathrm{yx} \%}$ \\
\hline \multicolumn{4}{|c|}{ Volume with bark and section $1,0 \mathrm{~m}$ long $\left(V_{l c c}\right)$} \\
\hline$a_{1}$ & 0.0000056 & & \\
\hline $\mathrm{b}_{1}$ & 1.4754620 & 0.9808 & \pm 9.16 \\
\hline $\mathrm{c}_{1}$ & 2.0073470 & & \\
\hline \multicolumn{4}{|c|}{ Volume with bark and section 2,0 $\mathrm{m}$ long $\left(V_{2 c c}\right)$} \\
\hline $\mathrm{a}_{2}$ & 0.0000059 & & \\
\hline $\mathrm{b}_{2}$ & 1.4822170 & 0.9792 & \pm 9.32 \\
\hline $\mathrm{c}_{2}$ & 1.9879680 & & \\
\hline \multicolumn{4}{|c|}{ Volume with bark and section 3,0 m long $\left(V_{3 c c}\right)$} \\
\hline$a_{3}$ & 0.0000066 & & \\
\hline$b_{3}$ & 1.4828770 & 0.9784 & \pm 10.13 \\
\hline$c_{3}$ & 1.9587790 & & \\
\hline
\end{tabular}

Table 6 - Testing of the identity of nonlinear models.

Tabela 6-Teste de identidade de modelos não lineares.

\begin{tabular}{cc}
\hline Statistics & Estimates \\
\hline$S Q R_{\Omega}($ complete model $)$ & 0.065760 \\
$S Q R_{w}($ reduced model $)$ & 0.066041 \\
$\chi_{\text {calculado }}^{2}$ & 0.512 \\
$\chi_{\text {tabelado }}^{2}$ & 12.6 \\
\hline
\end{tabular}

$\mathrm{SQR}=$ sum of the residue squares; $\chi^{2}=$ Chi square test.

This is due to the hypotheses tested, the data's distribution tendency, the tests' sensitivity to capture the differences and the probable inadequacy of the Chi-square test.

Graphic analysis of the differences between the volumes indicates that there is a tendency to overstimation of the total volumes with longer sections. The volumes found for sections $1.0 \mathrm{~m}$ long are, in general, lower than the volumes with $2.0 \mathrm{~m}$ sections, and this difference increases in the volumes obained with sections $3.0 \mathrm{~m}$ long (Figure 1). Analyzing the volume found with the $1.0 \mathrm{~m}$ section, there was a mean difference of $1.23 \%$ in relation to the volume found with $2.0 \mathrm{~m}$ sections and of $3,5 \%$ in relation to the volume results with the $3.0 \mathrm{~m}$ section.
Analyzing Figure 2, the tendency to overestimate the volumes is more pronounced in the basal part of the tree stems, where the volume is, percentually, higher. Therefore, it can be affirmed that the increase of the tree volume observed with the longer sections is a function, mainly, of this behavior.

In this way, shorter seções (1.0 and 2.0 meters) are recommendable for determining the volume of the tree stem base, where there is a greater variation of tree shape and higher volume percentage, while longer sections are more adequate to the top of the stem (HUSCH et al., 1993; MACHADO \& FIGUEIREDO FILHO, 2003). This recommendation is justified since, as tree length increases,

Cerne, Lavras, v. 16, n. 2, p. 155-162, abr./jun. 2010 

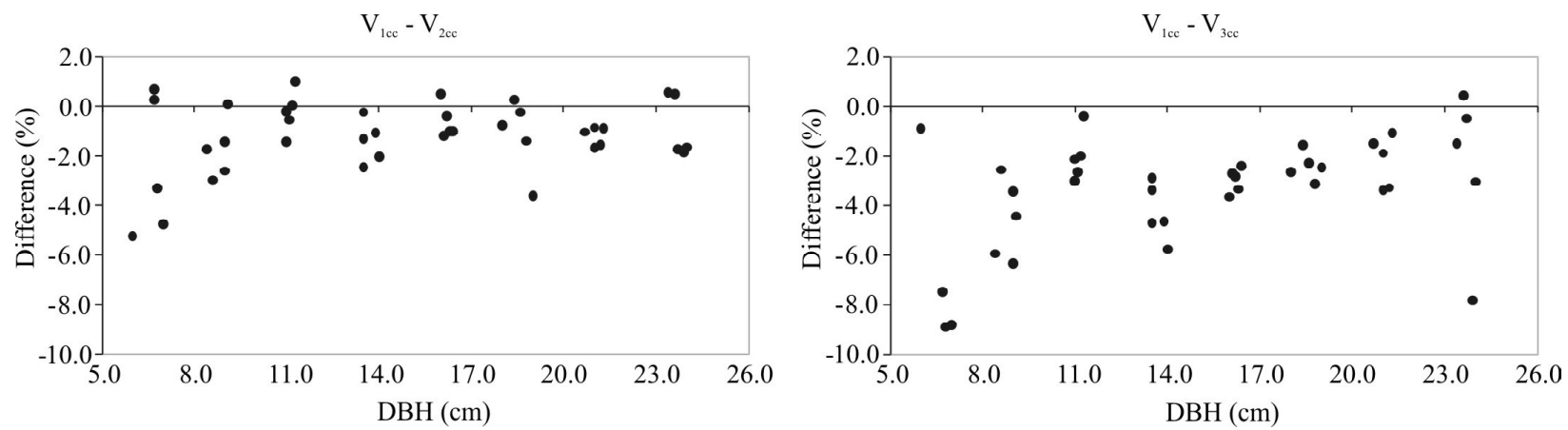

Figure 1 - Differences between the stem (with bark) volumes, determined through the Smalian formula, with section 1.0; 2.0 and 3.0 meters long $\left(\mathrm{V}_{1 \mathrm{cc}}, \mathrm{V}_{2 \mathrm{cc}}\right.$ e $\left.\mathrm{V}_{3 \mathrm{cc}}\right)$.

Figura 1 - Diferenças entre os volumes do fuste com casca, obtidos pela fórmula de Smalian, considerando seções de comprimentos iguais 1.0; 2.0 e 3.0 metros $\left(V_{1 c c}, V_{2 c c} e V_{3 c c}\right)$.
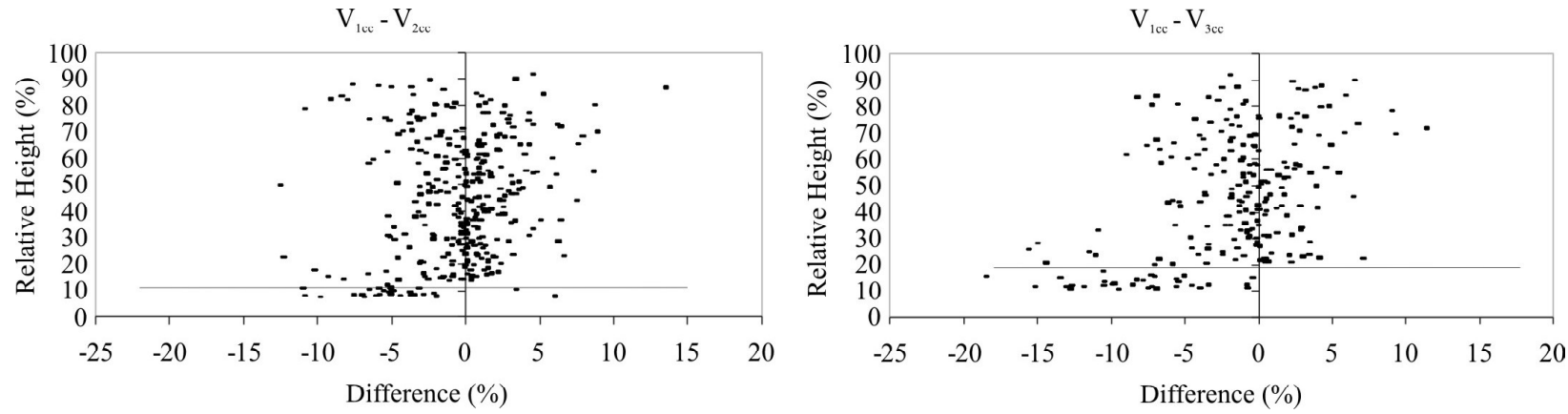

Figure 2 - Difference between the stem (with bark) volumes, determined through the Smalian formula, with sections $1.0 ; 2.0$ and 3.0 meters long $\left(\mathrm{V}_{1 \mathrm{cc}}, \mathrm{V}_{2 \mathrm{cc}} \mathrm{e}_{3 \mathrm{cc}}\right)$.

Figura 2 - Diferença entre os volumes do fuste com casca, obtidos pela fórmula de Smalian, considerando-se seções de comprimentos iguais a 1.0; 2.0 e 3.0 metros $\left(V_{1 c c}, V_{2 c c}\right.$ e $\left.V_{3 c c}\right)$.

the influence of section length on volume determination decreases. Therefore, although there is a sudden variation of the tree shape in the upper part of the trunk, there is little volume concentration, which does not justify the use of shorter sections at the top of the trunk. This suggestion of using shorter sections at the base and longer ones at the top is also made by Machado \& Figueiredo Filho (2003).

Husch et al. (1982) affirm that the Smalian formula may be applied to sections up to 4 feet long ( $\approx 1,22 \mathrm{~m}$ ). For longer seções, Newton and Huber's expressions provide more accurate stem volume estimates.

Various studies carried out by Machado \& Nadolny (1991) and Figueiredo Filho et al. (2000), and cited by Machado \& Figueiredo Filho (2003), corroborate this affirmation. In other words, the Smalian method presents greater volume estimate errors than the Huber and Newton, as the size of the scaled logs increases.

Cerne, Lavras, v. 16, n. 2, p. 155-162, abr./jun. 2010
The tendency to overestimate the stem (with bark) volumes when longer sections are used also poses difficulties to the application of the volume equations. Applying the adjusted equations in Table 5 to the total inventory plots, it was observed that the volume of the plots was always overestimated with the longer sections (Figure 3).

Therefore, inventory procedures that use volumetric equations adjusted with data obtained from longer sections may contain tendency or sampling errors, compromising the accuracy of the estimates.

Another aspect that should be considered is the possibility of an error in the description of the tree stem profiles by the taper functions. Longer sections, especially in the basal part of the tree stems, can lead to biased coefficientes, which implicates in a biased estimate of multiple volumes. 


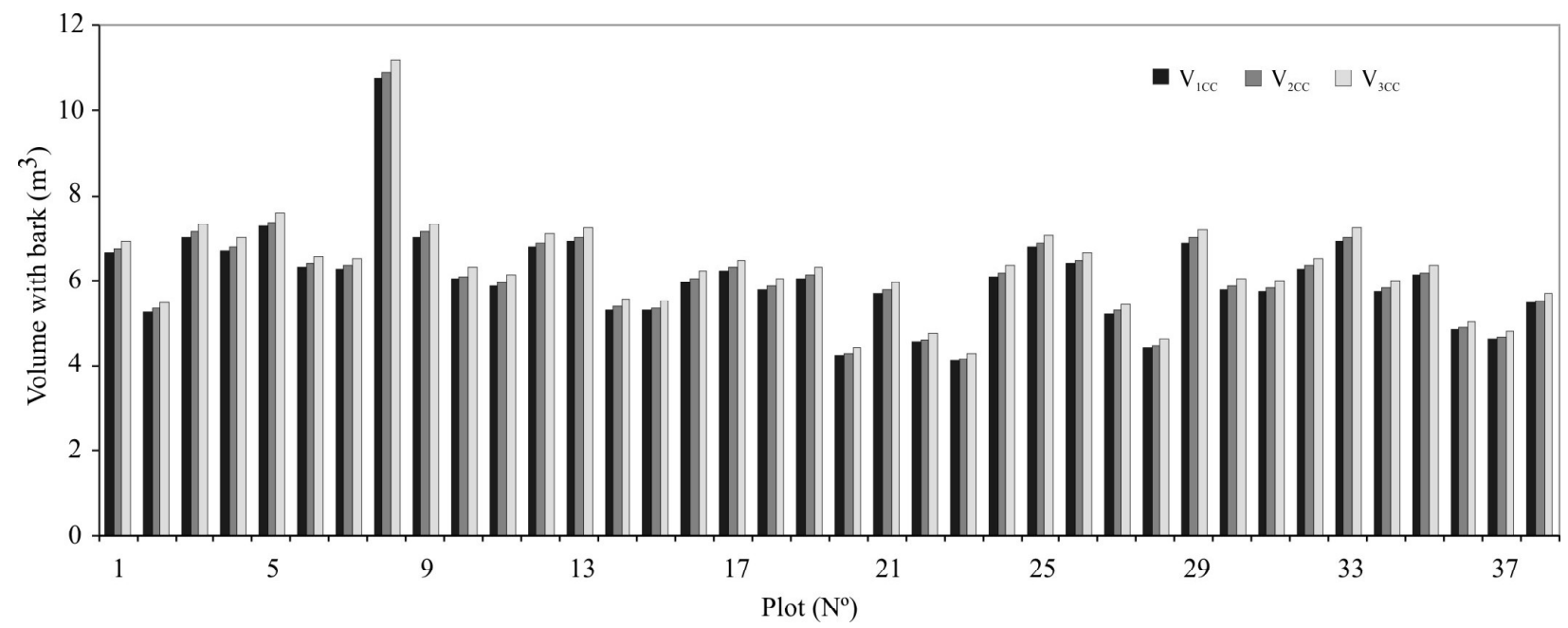

Figure 3 - Plot volumes determined from equations adjusted with sections 1.0; 2.0 and 3.0 meters long $\left(\mathrm{V}_{1 \mathrm{cc}}, \mathrm{V}_{2 \mathrm{cc}} \mathrm{e} \mathrm{V}_{3 \mathrm{cc}}\right)$.

Figura 3 - Volumes das parcelas obtidos com as equações ajustadas com comprimento de seções iguais a 1.0; 2.0; e 3.0 metros $\left(V_{1 c c}, V_{2 c c}\right.$ e $\left.V_{3 c c}\right)$.

\section{CONCLUSIONS}

Based on this study, the following can be concluded:

- longer sections lead to overestimations of the volume of the tree basal part and, consequently, of their total volumes;

- when using the Smalian formula, scaling with sections longer than $2.0 \mathrm{~m}$ should be avoided; shorter seções should be used in the basal part of the tree;

- different statistical tests led to different conclusions regarding the similarity of the volume estimates obtained in experiments using different section lengths;

- equations adjusted with volumes obtained from longer sections may introduce tendency errors in the forest inventory procedures.

\section{BIBLIOGRAPHICAL REFERENCES}

BRUCE, D.; SCHUMACHER, F. X. Forest mensuration. 3. ed. New York: McGraw-Hill Book, 1950. 483 p.

CAMPOS, J. C. C.; LEITE, H. G. Mensuração florestal: perguntas e respostas. 2.ed. Viçosa, MG: UFV, 2006. 470 p.

DRAPER, N. R.; SMITH, H. Applied regression analysis. 2. ed. New York: J. Wiley, 1981. 709 p.

FINGER, C. A. G. Fundamentos de biometria florestal. Santa Maria: UFSM/CEPEF/FATEC, 1992. 269 p.
GOULDING, C. J. Cubic spline curves and calculation of volume of sectionally measured trees. New Zealand Journal of Forest Science, Melbourne, v. 9, n. 1, p. 89-99, 1979.

HUCH, B.; MILLER, C. I.; BEERS, T. W. Forest mensuration. 2. ed. New York: J. Willey, 1982. 398 p.

HUCH, B.; MILLER, C. I.; BEERS, T. W. Forest mensuration. 3. ed. Florida: Krieger, 1993. 402 p.

KVALSETH, T. O. Cautionary note about $\mathrm{R}^{2}$. The American Statistician, Madison, v. 39, n. 4, p. 279-285, 1985.

LAAR, A. van; AKÇA, A. Forest mensuration. Netherlands: Springer, 2007. $383 \mathrm{p}$.

LOËTSCH, F.; ZÖHRER, F.; HALLER, K. E. Forest inventory. 2. ed. Munich: BLV Verlagsgesellschaft, 1973. v. 2, 469 p.

MACHADO, S. A.; CONCEIÇÃO, M. B.; FIGUEIREDO, D. J. Modelagem do volume individual para diferentes idades e regimes de desbaste em plantações de Pinus oocarpa. Ciências Exatas e Naturais, Curitiba, v. 4, n. 2, p. 185-196, 2002.

MACHADO, S. A.; FIGUEIREDO FILHO, A. Dendrometria. Curitiba: [s.n.], 2003. 309 p.

Cerne, Lavras, v. 16, n. 2, p. 155-162, abr./jun. 2010 
MACHADO, S. A.; MELlO, J. M.; BARROS, D. A. Comparação entre métodos para a avaliação de volume total de madeira por unidade de área, para o Pinheiro do Paraná, na Região Sul do Brasil. Cerne, Lavras, v. 6, n. 2, p. 55-66, 2000.

MACHADO, S. A.; TÉO, S. J.; URBANO, E.; FIGURA, M. A.; SILVA, L. C. R. Comparação de métodos de cubagem absolutos com o volume obtido pelo xilômetro para Bracatinga (Mimosa scabrella Bentham). Cerne, Lavras, v. 12, n. 3, p. 239-253, 2006.

MAGAlHÃES, M. N.; LIMA, A. C. P. de. Noções de probabilidade e estatística. 6. ed. São Paulo: USP, 2004. 392 p.

REGAZZI, A. J. Teste para verificar a igualdade de parâmetros e a identidade de modelos de regressão não-linear. Ceres, Viçosa, v. 50, n. 287, p. 9-26, 2003.

RIBEIRO, C. A. S.; SILVA, J. A. A.; FERREIRA, R. L. C.; MEUNIER, I. M. J.; FERRAZ, I. Seleção de modelos volumétricos para Leucena no agreste do estado de Pernambuco. Brasil Florestal, Brasília, v. 20, n. 72, p. 37-45, 2001.

SCHNEIDER, P. R. Análise de regressão aplicada a Engenharia Florestal. Santa Maria: UFSM, 1998. 236 p.

SCHNEIDER, P. R.; TONINI, H. Utilização de variáveis dummy em equações de volume para Acácia mearnsii. Ciência Florestal, Santa Maria, v. 13, n. 2, p. 121-129, 2003.
SCHUMACHER, F.; HALL, F. X. Logarithmic expression of timber-tree volume. Journal of Agricultural Research, Washington, v. 47, n. 9, p. 719-734, 1933.

SILVA, J. A. A.; PAULA NETO, F.; BRANDI, R. M. Análise de modelos volumétricos para a construção de tabelas de volume comercial para Eucalyptus spp., segundo a espécie, região e método de regeneração. Revista Árvore, Viçosa, v. 2, n. 1, p. 86-89, 1978.

SOARES, C. P. B.; PAULA NETO, F. de. Determinação do tamanho da amostra em um inventário volumétrico e de biomassa de troncos. Revista Ceres, Viçosa, v. 44, n. 252, p. 142-151, 1997.

SOARES, C. P. B.; PAUlA NETO, F.; SOUZA, A. L. Dendrometria e inventário florestal. Viçosa, MG: UFV, 2006. $276 \mathrm{p}$.

TONINI, H.; ARCO-VERDE, M. F.; SÁ, S. P. P. Dendrometria de espécies nativas em plantios homogêneos no estado de Roraima Andiroba (Carapa guianensis Aubl), Castanha-do-Brasil (Bertholletia excelsa Bonpl.), Ipê-roxo (Tabebuia avellanedae Lorentz ex Griseb) e Jatobá (Hymenaea courbaril L.). Acta Amazônica, Manaus, v. 35, n. 5, p. 353-362, 2005.

VIANELLO, R. L.; ALVES, A. R. Meteorologia básica e aplicações. Viçosa, MG: UFV, 1991. 449 p. 